\title{
Using object-oriented image analysis to map and monitor land cover change in the Region Costa Maya, México: 1993-2010
}

\author{
Morgan Simbangala Simbangala',1113549@uqroo.mx; Bonnie Lucía Campos \\ Cámara $^{1}$; Lourdes Castillo Villanueva ${ }^{1}$; Óscar Frausto Martínez ${ }^{1}$; David Velázquez \\ Torres $^{1}$; Rafael Romero Mayo ${ }^{1}$; María Estela Orozco Hernández ${ }^{2}$
}

\begin{abstract}
Accurate, cost effective and timely multiple spatial-temporal information on the patterns of land cover change is crucial for environmental management and understanding. For this reason, segmentation and object-oriented classification was applied to Landsat TM/ ETM+ imagery to map and monitor land cover dynamics in the Región Costa Maya (RCM) in 1993, 2000 and 2010. Overall mapping accuracy for land-cover map in 2000 was $94.29 \%(\kappa=0.9141)$. Post-classification approach, involving cross tabulation of three generated maps, was used to characterize spatial-temporal rates and patterns of land cover change to infer major processes of changes over 17 years. Results revealed rapid urbanization, agricultural land abandonment (forest transition) and destruction of mangrove forests, mediated by socio-economic factors linked to tourism development as the leading drivers of land cover change, with grave implications on environmental sustainability in the Costa Maya area. The study has confirmed the value of segmentation and object-oriented classification for mapping and monitoring land cover change at regional scale.
\end{abstract}

Keywords: change detection, object-oriented classification, image segmentation, remote sensing, Landsat images.

\section{Análisis de imágenes orientadas a objetos para mapear y monitorear cambios en la cobertura terrestre de la Región Costa Maya, México: 1993-2010}

\section{RESUMEN}

La información espacio-temporal múltiple, precisa, rentable y pertinente sobre los cambios en la cobertura del suelo es fundamental para el mejor manejo del medio ambiente. De esta forma, en este estudio se aplicó la segmentación y clasificación orientada a objetos a las imágenes de Landsat TM / $\mathrm{ETM}+$ para mapear la cobertura del suelo en la Región Costa Maya, de 1993, 2000 y 2010. Se obtuvo una precisión global de mapeo del mapa del año 2000 de 94,32\% $(\mathbf{\kappa}=0.9141)$. Para caracterizar las tasas y los patrones espacio-temporales de cambio en la cobertura terrestre, se aplicó la comparación en post-clasificación, utilizando tabulaciones cruzadas de tres mapas, posteriormente generados, para inferir los principales procesos de cambios durante 17 años. Los resultados revelaron una rápida urbanización, el abandono de tierras agrícolas (transición forestal) y la destrucción de los manglares, mediado por factores socio-económicos vinculados al desarrollo del turismo, como los principales impulsores del cambio, con graves implicaciones sobre la sostenibilidad del medio ambiente en la Costa Maya. El estudio ha confirmado el valor de la segmentación y clasificación orientadas a objetos en el mapeo y monitoreo del cambio de cobertura terrestre a escala regional.

Palabras clave: detección de cambio, clasificación orientada a objetos, segmentación de imágenes, teledetección (percepción remota), imágenes Landsat.

Recibido el 18 de octubre de 2015, aceptado el 3 de diciembre de 2015.

1 División de Ciencias e Ingeniería, Universidad de Quintana Roo, Boulevard Bahía esq. Ignacio Comonfort, Colonia del Bosque, C.P. 77019, Chetumal, Quintana Roo, México.

2 Facultad de Planeación Urbana y Regional, Universidad Autónoma del Estado de México, Toluca, Estado de México, México. 


\section{INTRODUCTION}

The earth needs constant monitoring of its rapidly changing landscapes to ensure its health and sustainability. Environmental damage just like any chronic disease requires regular and up-to-date diagnoses to improve treatment. Landscape change is a result of complex interactions between land-cover and land-use reflecting a variety of environmental and social factors, and poses the largest threat to the ecological system (LAMBIN et al., 2003; GEIST et al., 2006). To understand landscape changes it is necessary to monitor and characterize spatial and temporal patterns of land cover change (PETIT et al., 2000). This is important because precise information on land cover change such as location, extent, and cause is crucial for an improved analysis and management of natural resources and urban development (WANG et al., 2009).

The Región Costa Maya is an example of an area experiencing rapid land cover changes. Established in 1991 by the state government as an engine to stimulate the development of the southern Quintana Roo a region that has experienced massive development, mainly in tourism and related infrastructure, which has turned it into one of the most important tourism destinations, attracting tourists from across the world (CAMPOS-CÁMARA 2010). Tourism is significant for the prosperity of the region, but it has also led to increased hazards to its environment in the form of increased migration, uncontrolled urbanization and great pressure on natural resources (CASTILLO-VILLANUEVA et al., 2010); even though the region is subject to various instruments for environmental protection and management (Programa de Ordenamiento Ecológico del Territorio $P O E T$ ) which regulate economic, tourism and urban developments and envisage the restoration, protection, conservation and rational use of natural resources (GONZÁLEZ-VERA 2010; VÁZQUEZTREJO, 2010).
Left unchecked, the aforementioned threats could eventually lead to land degradation, which might not only compromise human well-being, but also tourism, which is the principal economic activity in the Región Costa Maya. Hence, it is imperative to examine these factors within the context of sustainable land use in order to stave off environmental deterioration. Given the spatial and temporal scales of concern, satellite remote sensing seems to be the only cost-effective and feasible way of acquiring the necessary information about the environment (FOODY 2003). Thus, the objectives of this study are: (1) to develop an appropriate remote sensing methodology using Landsat TM/ETM+ data to monitor land cover changes in Región Costa Maya; (2) to draw land cover maps for the same area during the years 1993, 2000 and 2010; (3) to identify land cover trends during this period.

This study implies two main procedures, namely the drawing up of land cover maps and the implementation of change detection analysis. Among its key output is a set of validated datasets describing land covers in the study area, which will be useful to develop models to provide further insights into the process of landscape change.

Background (Landscape change detection)

GEIST et al. (2006), suggested that any land cover-change study should be implemented following two fundamental steps, namely detecting change in the landcover, and ascribing that change to a set of causal factors. Remote sensing is a valuable data source from which land cover change information over a range of spatial and temporal scales can be extracted efficiently and cheaply (LAMBIN 1997). Monitoring land cover variations can be accomplished by analyzing multi-temporal land use/cover maps or by multi-date remotely sensed image processing. This is a technique known as change detection, whose basic principle, according to MAS, (1999) is that any 
changes in land cover produce detectable differences in the spectral response of ground targets. Change detection has become a critical and universal tool for natural resource managers and researchers in governmental agencies, conservation organizations and industry. LU et al. (2004) provides an excellent review of its range of applications which include: land use/cover change; urban change; forest or vegetation change; deforestation and regeneration; wetland change and others.

Output from remote sensing analyses is typically quantitative and repeatable (PRENZEL 2004). Hence, effective change detection research should give insight into the quantity, location and nature of land cover changes (ASPINALL \& HILL 2008). A successful implementation of change detection depends on several factors such as natural status of the area, selection of appropriate remote sensing data and analysis techniques (COPPIN et al., 2004; LU et al., 2004). Another crucial consideration in remote sensing application is in-situ information collection, which is essential for calibration purposes and integration of other tools like GIS and GPS to improve result accuracy (ESWARAN et al., 2001).

Recent technological progress in remote sensing and associated digital image processing techniques offer unprecedented opportunities to more accurately map land cover. One relatively new technique that has not been used extensively in land cover mapping, but which shows considerable possibilities of development, is segmentation and object-oriented image processing (FROHN et al., 2009). It refers to the classification of homogeneous image primitives, i.e. groups of pixels that closely resemble the size and shape of features in the real world scene such as lakes, urban areas, cropland, forests and urban areas, rather than the individual pixels of any given remote sensing imagery (BLASCHKE et al., 2014). Compared to traditional pixel-based change paradigm this approach has shown excellent potential to improve accuracy in land cover mapping (BLASCHKE 2013; NAVULU 2007; LIU \& XIA 2010), yet only a handful of peer-reviewed studies in Mexico have applied it to Landsat data. Thus, in this study we apply segmentation and object-oriented processing to Landsat TM/ ETM+ imagery to map and monitor land cover in Región Costa Maya over a 17year period.

\section{MATERIALS AND METHODS}

\section{Study area}

The Región Costa Maya is located in the Municipality of Othón P. Blanco, Quintana Roo, on the southeastern extreme of the Yucatan peninsula, between coordinates $19^{\circ} 05 \mathrm{~N}, 87^{\circ} 35 \mathrm{~W}$ and $18^{\circ} 10 \mathrm{~N}, 87^{\circ} 33$ W. Its boundaries are the Caribbean Sea to the east, the Sian Káan Biosphere Reserve to the north, the Bacalar lagoon to the west and the State of Belize to the south. Local topography is generally flat, averaging about $8 \mathrm{~m}$ above mean sea level. Geologically, it is a karst environment characterized by thin limestone-derived soils (mostly lithosol and rendzinas) and a system of underground drainage systems and sinkholes.

Warm humid tropical climate with summer rainfall (between May and October) prevails in the region. The vegetation comprises mainly of tropical forest, lowland forest, pasture and cultivated areas, while the coastal strip is characterized by mangroves and marshes. 


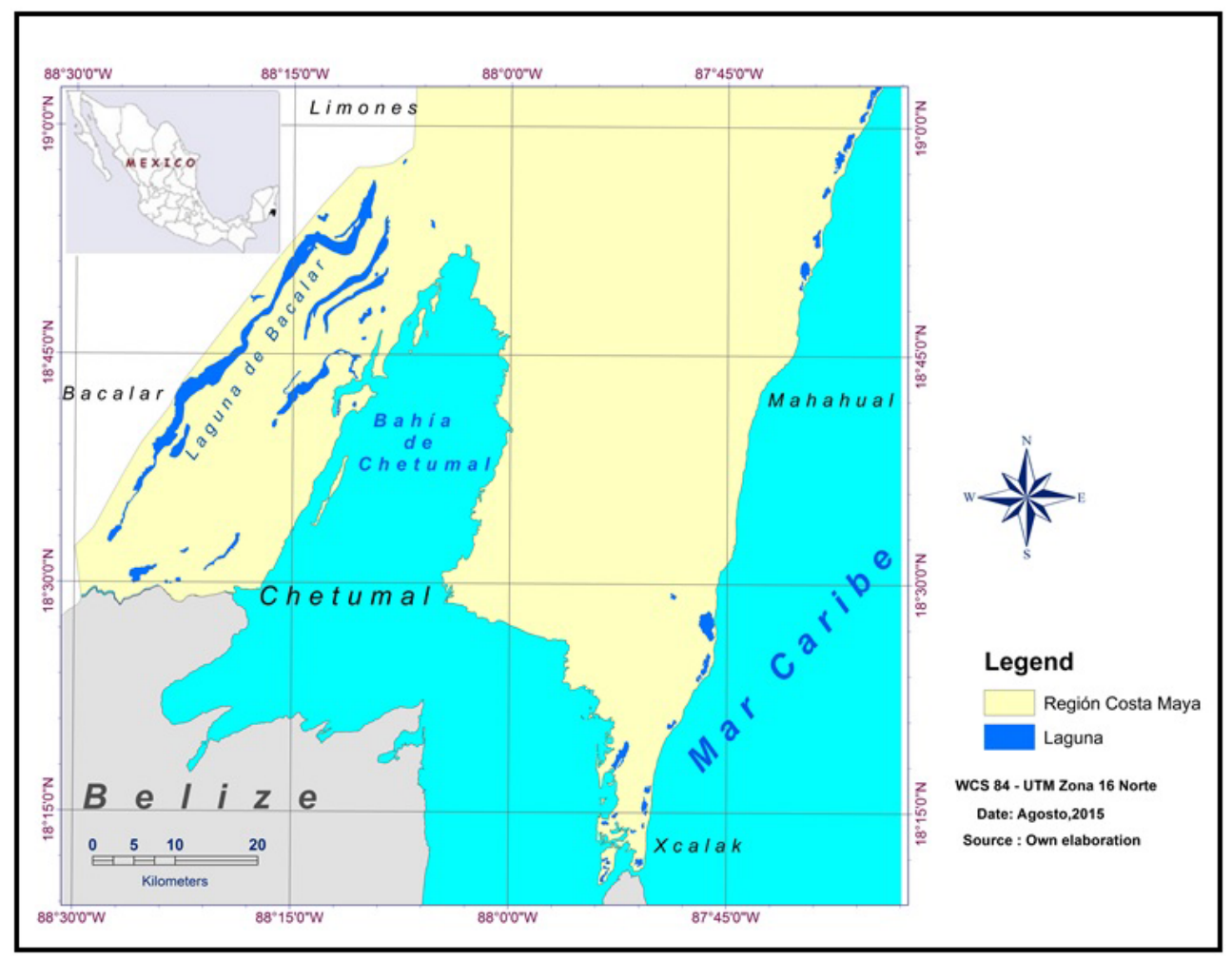

Fig. 1. Study area.

Fig. 1. Área de estudio.

The marine ecosystem is integrated into the Mesoamerican barrier reef, the second largest in the world. Chetumal, Bacalar, Majahual and Xcalak are the main urban centers in the Región Costa Maya, with Chetumal, the state capital, showing the greatest population concentration of $58.4 \%$ in 2000 , rising to $62.3 \%$ in 2005 (CASTILLO-VILLANUEVA et al., 2010). Tourism, fishing, agriculture and forestry are the main economic activities in the Región Costa Maya.

\section{Data}

Analysis of land cover change was based on three land cover maps dated 10/04/1993, $09 / 02 / 2000$ and $14 / 02 / 2010$, derived from Landsat TM/ETM+ images (Path 19, Row 47) downloaded for free from the United States Geological Survey's Landsat archives. Images were selected in order to minimize environmental fluxes affecting the change detection results (SINGH 1989). Being located in the subtropical zone, the Región Costa Maya tends to be cloudy throughout the year. So, images were taken during the dry season (NovemberMarch) to take advantage of cloud-free windows, which unfortunately were not available at precise anniversary dates. Luckily, the United States Geological Survey had already orthorectified the three images to the UTM zone 16 North (map projection) and WGS 84 (datum and ellipsoid, NAD27) corresponding to Quintana Roo and so, only radiometric correction was deemed necessary. Ancillary data for selecting training areas and testing image classification included the Mexican National Institute for Statistics, Geography and Demographics (INEGI) Series IV 
topographical map, some historical photos and Google Earth.

\section{Preprocessing}

Preprocessing steps included radiometric calibration and image segmentation using Idrisi Selva ${ }^{\circledR}$ software.

\section{Radiometric calibration}

With the aim of removing atmospheric effects and making images comparable between the dates, we applied the $\operatorname{Cos}(t)$ model, which is an image-based absolute correction application in Idrisi Selva that removes haze and normalizes images using data that can be found or calculated from accompanying image metadata(EASTMAN 2012). We ignored the Full Correction model as we did not have historical in-situ meteorological data to input into the said model. Besides, the reflectance values computed by the $\operatorname{Cos}(t)$ model have been found to closely approximate values derived from much more demanding models requiring in-situ atmospheric measurements (CHÁVEZ, 1996).

\section{Classification scheme}

Jensen (1996) warns that if a reputable classification system already existed, it would be unwise to develop an entirely new system that would probably be used only by us. A classification scheme defines the specific land use or land cover categories that are required for a given application; it is generally better to use a well-accepted classification scheme and adjust the various class definitions to suit the project at hand (NARUMALANI et al., 2005). Accordingly, we adopted the INEGI classification scheme to allow us to interpret the significance of classification results in light of the other studies and to make it easier to share data. The scheme comprised of five generalized classes: water, urban area (and built-up surfaces), agriculture (cultivated area and pastures), hydrophytic vegetation, mangroves and tropical forest.

\section{Segmentation and object-oriented classification}

One critical step in object-oriented classification before implementing image classification is the production of suitably segmented images and this entails grouping contiguous pixels into objects having defined level of spectral homogeneity (BLASCHKE et al., 2014). To achieve this, we selected a subset of three bands (3, 4 and 5) from each Landsat scene and segmented them into objects using the Idrisi Selva ${ }^{\circledR}$ 'multi-resolution segmentation' algorithm. This is a semi-automated process where the user can define specific input parameters to tune the algorithm to the correct scale of analysis, and then a supervised classification can be applied on the segmented image (EASTMAN 2012). Unfortunately, there are no standard values for these variables (FROHN et al., 2009) as different kinds of images not only require different scales of analysis, but also because significant objects may appear at different spatial scales of analysis in the same image (BLASCHKE et al., 2011). Hence, to run the model, we performed several iterations of similarity tolerances by trial and error, until we found a combination of values (Table 1) that produced the best output, based on the visual inspection. We used the same parameters in the final segmentation of the three dates.

Lastly, using sample objects, selected as representative of land cover classes interpreted from INEGI topographical map, expert knowledge and Google Earth ${ }^{\circledR}$, we produced land cover maps for 1993, 2000 and 2010 (Fig. 2) by supervised classifications of each date using maximum likelihood algorithm. 
TABLE 1. Summary OF SEgMENTATION PARAMETERS OF PIXELS FOR THE DATES: 1993, 2000 AND 2010.

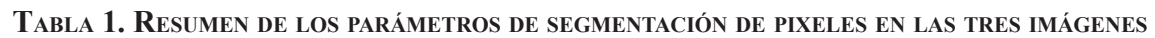
SATELITALES: 1993, 2000 Y 2010.

\begin{tabular}{|c|c|c|c|c|c|c|}
\hline $\begin{array}{c}\text { Segmentation } \\
\text { parameters }\end{array}$ & Bands & Weight & $\begin{array}{c}\text { Window } \\
\text { size }\end{array}$ & Weight-mean factor & Weight-variance factor & Similarity tolerance \\
\hline Value & $3,4,5$ & $0.3 / 0.4 / 0.3$ & 3 & 0.5 & 0.5 & $35 / 40 / 70$ \\
\hline
\end{tabular}

Source: own elaboration.

\section{Accuracy assessment}

Land cover maps derived from remote sensing always contain some sort of errors due to several factors ranging from classification techniques to methods of satellite data capture, which can affect the change process with omission and commission errors (CONGALTON \& GREEN, 2009). Hence, it is necessary to assess the accuracy of the derived maps not only to gauge map quality, but also the effectiveness of classification procedures used (CONGALTON, 2004). This is most effectively done by implementing an accuracy assessment (FOODY, 2002). However, carrying out a proper accuracy assessment can be time- consuming and costly, this is the main reason why this crucial step is often overlooked in many mapping projects (CONGALTON \& GREEN, 2009; HORNING, et al., 2010). In this study, an accuracy assessment only on land cover map 2000, for which there was reliable historical reference data, following procedures outlined in EASTMAN (2012) was performed.

Firstly, a set of 210 random sample locations was generated using Idrisi Selva's stratified random sample module. Then the true land covers at these locations were determined, with the help of INEGI, Series IV topographical Map, Google Earth, expert knowledge and familiarity with the area of study and some limited fieldwork. Finally, the validated land cover classes against those mapped in land cover map 2000 using an error matrix (Table 2) was compared to derive the overall classification accuracy, omission (producer's accuracy), commission (user's accuracy) errors and a $\boldsymbol{\kappa}$ coefficient. The definitions and computations of the aforementioned terms have been described extensively in remote sensing literature (JENSEN, 1996; LILLESAND, et al., 2004; CONGALTON \& GREEN, 2009; CAMPBELL \& WYNNE, 2011).

\section{Change detection analysis}

Change detection was accomplished by cross-tabulating 1993, 2000 and 2010 land cover maps. The post-classification comparison technique because it allows detection and mapping of amount, location and nature of land cover change was applied (LU, et al., 2004). Three classified maps were loaded onto Idrisi Selva and implemented the Land Change Modeler $(L C M)$ which allowed us to quickly map and analyze spatial distribution of different land cover classes, land cover changes and spatial trends in transitions between landcover categories in the landscape over time (EASTMAN, 2012).

As the potential combinations of transitions can be complex with many land-cover classes, to simplify analysis in this study we focused on the transitions linked to human activities. Also, considering that land transformation is not linear (URIARTE, et al., 2010). The average annual rate of change $(R)$ for each class with the formula proposed by PUYRAVAUD (2003) was calculated that is: 
$\left.R=\left(\mathrm{A}_{2} / \mathrm{A}_{1}\right)^{(1 / \mathbf{t}}-\mathbf{t}\right)-1$

Where: $A_{2}$ and $A_{1}$ are the class areas at the end $\left(t_{2}\right)$ and the beginning $\left(t_{1}\right)$, of the period being evaluated, and $t_{2}-t_{1}$ is the number of years spanning that period.

\section{RESULTS}

\section{Land cover classification}

Figure 2 represents the land cover maps generated for 1993, 2000 and 2010. The individual class areas and change statistics for the three dates are summarized in Table 3.

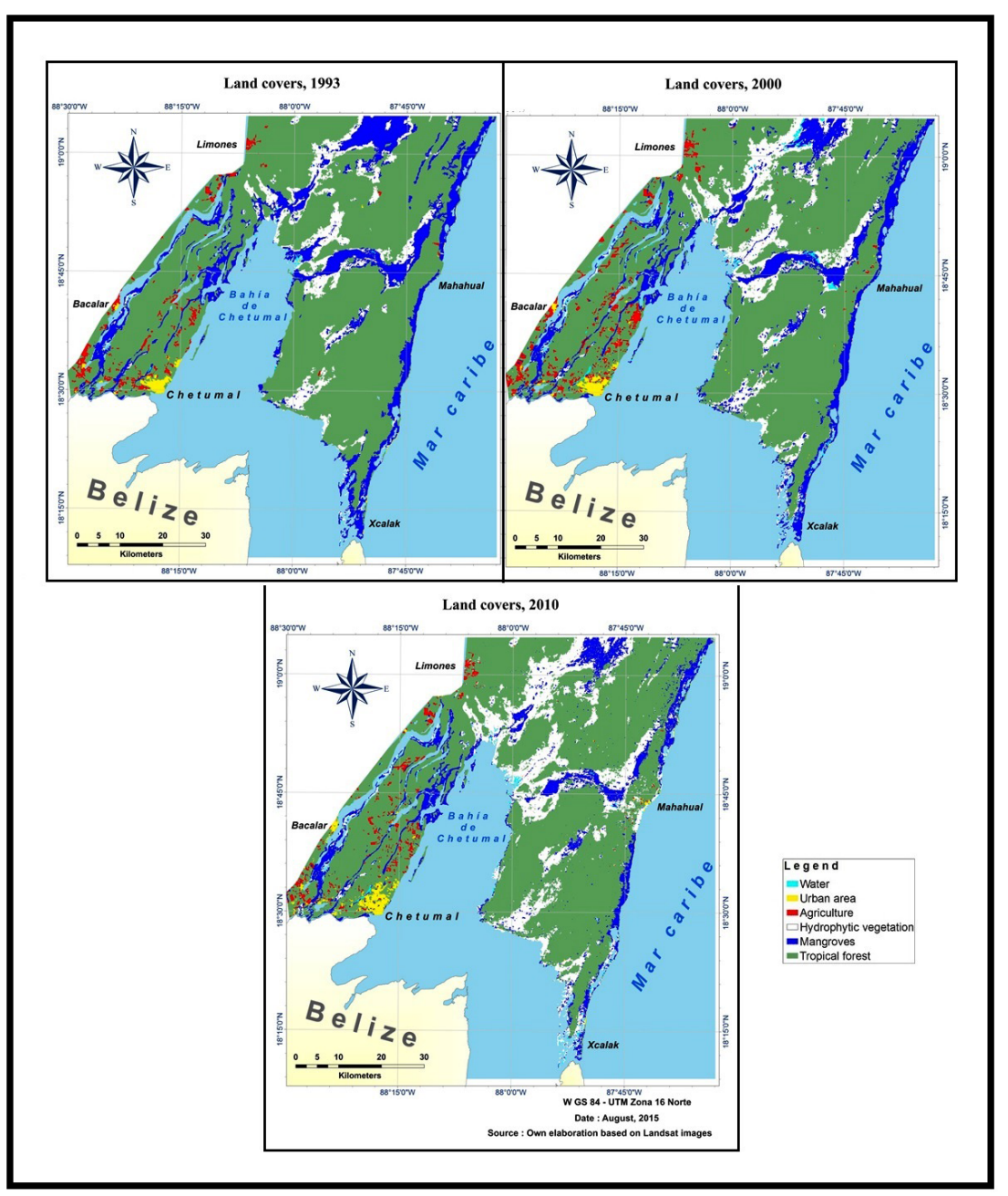

Fig. 2. LAND-COVER MAPS FOR 1993, 2000 AND 2010.

Fig. 2. Mapas de cobertura de Suelo, 1993, 2000 y 2010. 
Apart from water ( $45 \%)$, the prevalence of tropical forests in the landscape is evident; maps show their gradual fragmentation, appearing smoother in 1993 and patchier in succeeding years. Wetlands (hydrophytic vegetation and mangroves collectively) constitute the third largest class in the Región Costa Maya, where hydrophytic vegetation can be observed as steadily spreading at the expense of mangroves. Agriculture, the fourth largest land cover class in the region is mainly concentrated in the fresh water basin of Bacalar Lake and Hondo River. The urban area class comprises of the smallest area of the study and is mainly prominent around major towns both inland and along the Caribbean coast.

\section{Mapping accuracy achieved}

Table 2 shows that the overall mapping accuracy of the land-cover map 2000 was $94.29 \%$ with a $\boldsymbol{\kappa}$ coefficient of 0.9141 .

Table 2. Error matrix for Classified map 2000, with Producer's, User's and Overall Accuracy by Class.

TABla 2. MATRIZ DE ERROR ENTRE CLASES DEL MAPA 2000, CON FIABILIDAd DEL PRODUCTOR, DEL USUARIO Y EXACTITUD (FIABILIDAD) GLOBAL.

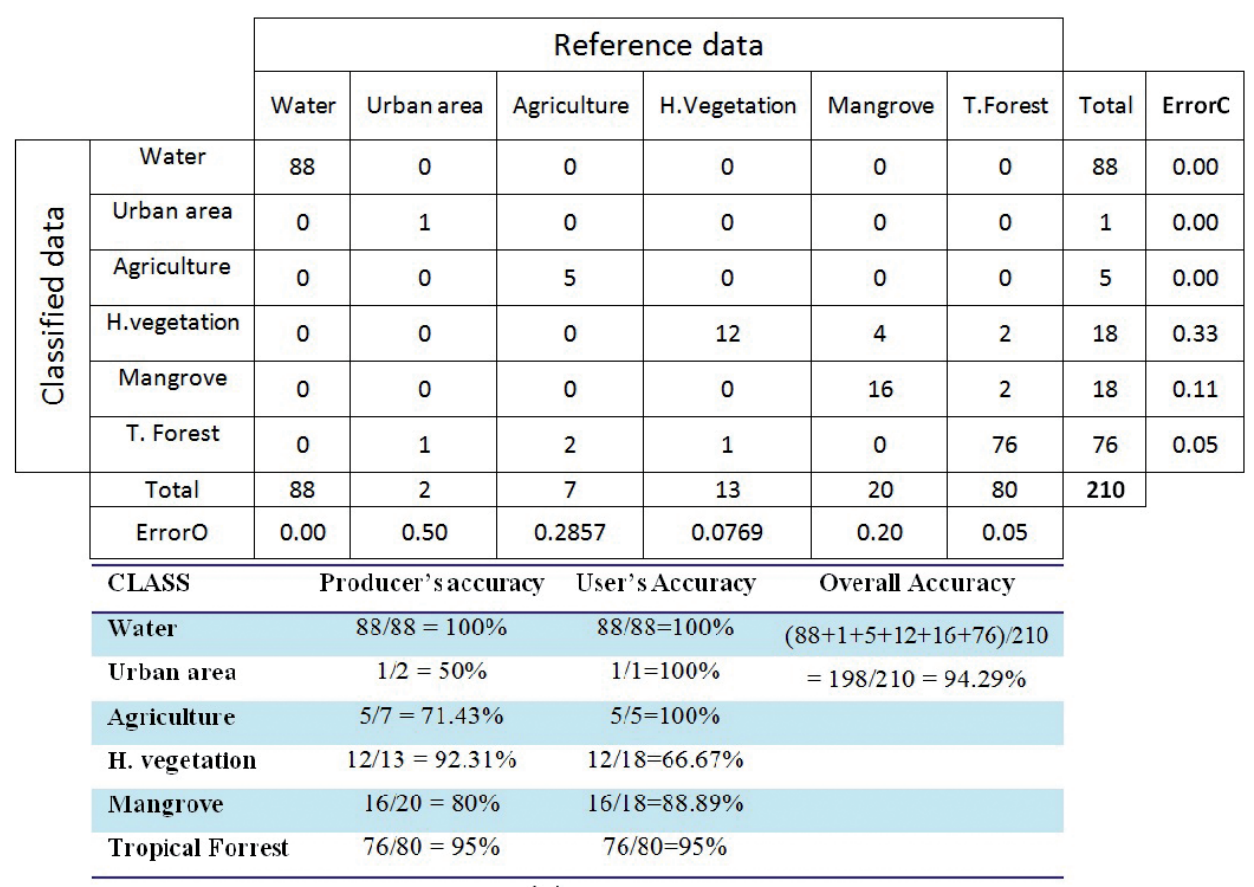

Source: own elaboration.

The highest producer accuracies ( $>80 \%)$ resulted from sampling relatively homogenous classes (water bodies, h. vegetation and tropical forest), while lowest producer accuracies were associated with mixed classes (urban and agricultural areas). In contrast, lowest user accuracies were linked to sampling closely related classes i.e., mangroves and hydrophytic vegetation.

According to FOODY (2002), land cover elements should be mapped at an accuracy of about $85 \%$ or more. On the other hand, 
$\boldsymbol{\kappa}$ coefficient values (range: -1 and +1 ) ought to be divided into four qualitative groupings: values lower than 0.4 represent poor or very poor agreement, values from 0.4 to 0.55 represent fair agreement, values from 0.55 to 0.7 represent good agreement, values from 0.7 to 0.85 represent very good agreement, and values higher than 0.85 represent excellent agreement between images (MONSERUD \& LEEMANS 1992).

\section{Land cover change analysis}

The analysis of the spatial patterns of landcover changes underpins the third objective of this study: to characterize the land cover trends in the region. Fig. 3 represents two cross-classified maps (1993-2000 \& 20002010) which depicts persistence, i.e. areas where no change occurred between land cover classes (in green) and the inter-class spatial patterns of conversions between the dates (in other colors). One obvious feature on these maps is the sharp increase and then the decline of agricultural areas on the mainland west of the Bahía de Chetumal (Chetumal Bay) from 1993-2000 and 20002010 respectively, mainly due to their conversion to tropical forests.

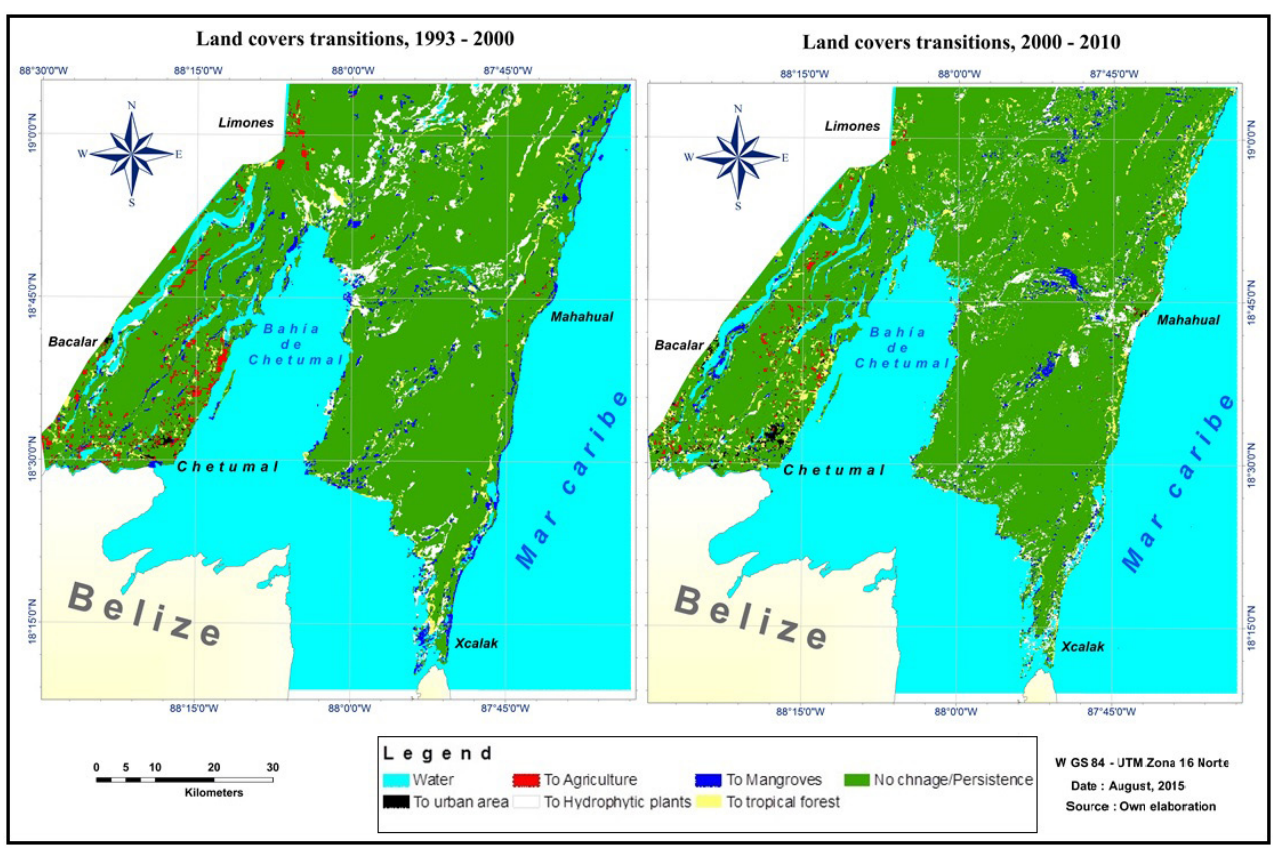

Fig. 3. Spatial pattern of Land Cover changes between Dates.

Fig. 3. Patrón espacial de cambio en la cobertura terrestre entre las fechas.

Another prominent change is the marked expansion of urban zones, especially around Chetumal and Mahahual, probably as a result of natural growth. Another noteworthy change is the fragmentation of the wooden vegetation classes (tropical and mangrove forest) around major urban areas, especially in Mahahual. 


\section{Magnitude and rates of land cover changes}

Table 3 and Fig. 4 respectively, provide quantitative information about the magnitude of each land cover type and its rate of change. Negative values denote a decrease in the rate and magnitude of change in the land cover type. Hydrophytic vegetation expanded significantly in all the sub periods (by $169.56 \mathrm{Km}^{2}$ from 19932000 , at $5.02 \%$ per annum and by 87.78 $\mathrm{km}^{2}$ from $2000-2010$, at $1.41 \%$ per annum) corresponding to an overall net annual increase of $2.88 \%$ for the entire study period. In contrast, mangroves declined steadily from $1993-2000$ by $86.85 \mathrm{Km}^{2}$ at $-2.3 \%$ per year, and from $2000-2010$ by $93.43 \mathrm{Km} 2$ at $-2.11 \%$ per year, maintaining an overall annual decline rate of $-2.2 \%$.

TABLE 3. LAND COVER AND ITS CHANGe BETWEen DATES.

Tabla 3. Cobertura del SUelo y SU Cambio entre las Fechas.

\begin{tabular}{|c|c|c|c|c|c|c|c|c|}
\hline \multirow{2}{*}{ Land cover } & \multicolumn{2}{|c|}{ Coverage in 1993} & \multicolumn{2}{c|}{ Coverage in 2000 } & \multicolumn{2}{c|}{ Coverage in 2010 } & \multicolumn{2}{c|}{ Changes } \\
\cline { 2 - 9 } & $\mathbf{( \mathbf { K m } ^ { 2 } )}$ & $\mathbf{\%}$ & $\mathbf{( \mathbf { K m } ^ { 2 } \mathbf { ) }}$ & $\mathbf{\%}$ & $\mathbf{( \mathbf { K m } ^ { 2 } )}$ & $\mathbf{\%}$ & $\mathbf{1 9 9 3 - 2 0 0 0}$ & $\mathbf{2 0 0 0 - 2 0 1 0}$ \\
\hline Water & 3339.23 & 45.604 & 3352.52 & 45.786 & 3356.28 & 45.837 & 13.29 & 3.76 \\
\hline Urban area & 24.72 & 0.338 & 28.23 & 0.386 & 47.46 & 0.648 & 3.51 & 19.23 \\
\hline Agriculture & 59.93 & 0.818 & 96.47 & 1.318 & 59.90 & 0.818 & 36.54 & -36.57 \\
\hline H. vegetation & 414.78 & 5.664 & 584.34 & 7.980 & 672.12 & 9.179 & 169.56 & 87.78 \\
\hline Mangrove & 572.35 & 7.817 & 485.50 & 6.630 & 392.07 & 5.355 & -86.85 & -93.43 \\
\hline Forest & 2911.21 & 39.759 & 2775.16 & 37.900 & 2794.39 & 38.163 & -136.05 & 19.23 \\
\hline Total & $7,322.22$ & 100 & $7,322.22$ & 100 & $7,322.22$ & 100 & 0 & 0 \\
\hline
\end{tabular}

Source: own elaboration.

+ : increase in coverage; - : decrease in coverage.

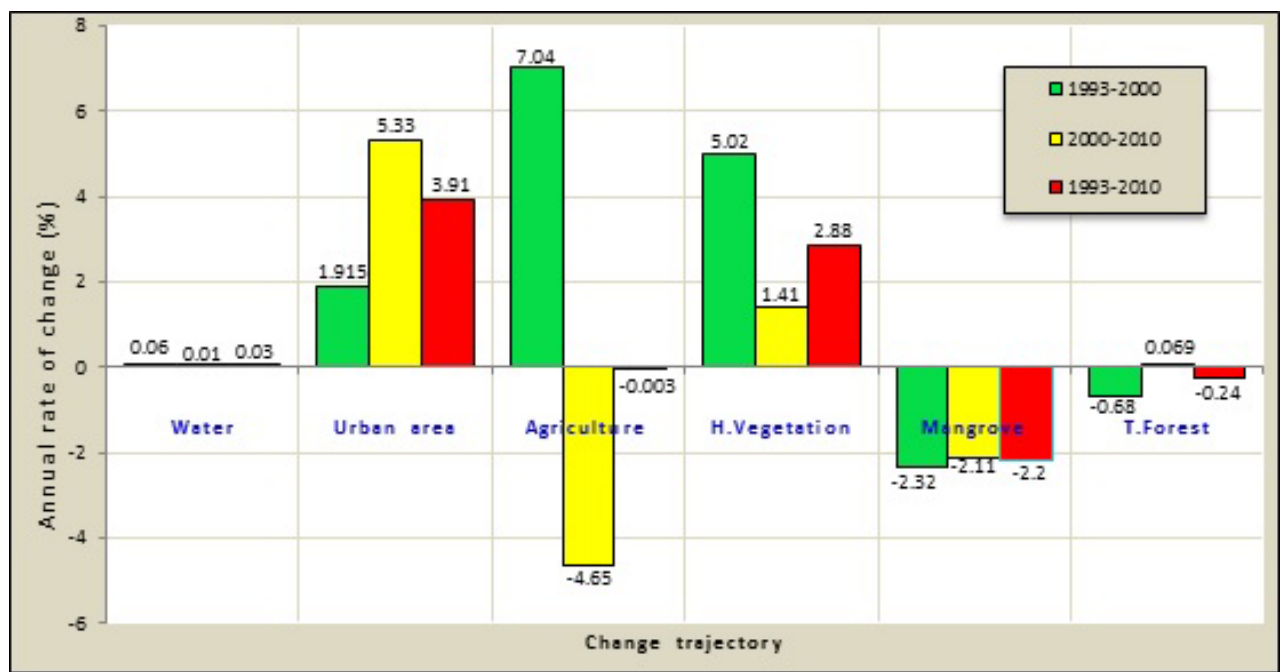

Source: own elaboration.

Fig. 4. RATES OF LAND COVER CHANGe DURING THE PERIODS: 1993-2000, 2000-2010 AND 1993-2010.

Fig. 4. TASA anUal de CAMbio en COBERTURa terrestre durante 1993-2000, 2000-2010 y 1993-2010. 
A large decline of tropical forest cover $\left(136.06 \mathrm{Km}^{2}\right)$ took place in the period 19932000 , at an annual rate of $-0.68 \%$ (Fig. 4). Later the trend reversed during the second period, whereupon a slow increase in forest cover $\left(19.23 \mathrm{Km}^{2}\right)$ at a rate of $0.07 \%$ per annum occurred, reflecting an annual net loss of $-0.24 \%$, for the entire study period. Agricultural areas presented an interesting result: they gained $36.56 \mathrm{Km}^{2}$ (at $7.04 \%$ per annum) from 1993-2000, only to lose by nearly the same amount (at $-4.65 \%$ per annum) from 2000-2010, reflecting a negligible net annual rate of change for the entire study period. In contrast, urban area class exhibited an intense spatial increase in both sub periods. It spread by $3.51 \mathrm{Km}^{2}$ (at $1.91 \%$ per annum) from 1993 to 2000 before sharply increasing its area, roughly fivefold, to $19.23 \mathrm{Km}^{2}$ (at $5.99 \%$ per annum) between 2000 and 2010, reflecting an overall net annual rate $3.91 \%$ for the entire study period.

\section{Nature of changes among land covers}

Some classes contributed to variations in other categories (Fig. 5). For instance, Urban gained primarily from Agriculture and Forests, but lost to Mangrove from 19932000. Between 2000 and 2010, contribution to net change in Urban from both Forest and Agriculture at least doubled, and Urban also recovered its losses from Mangroves during the period 2000-2010.

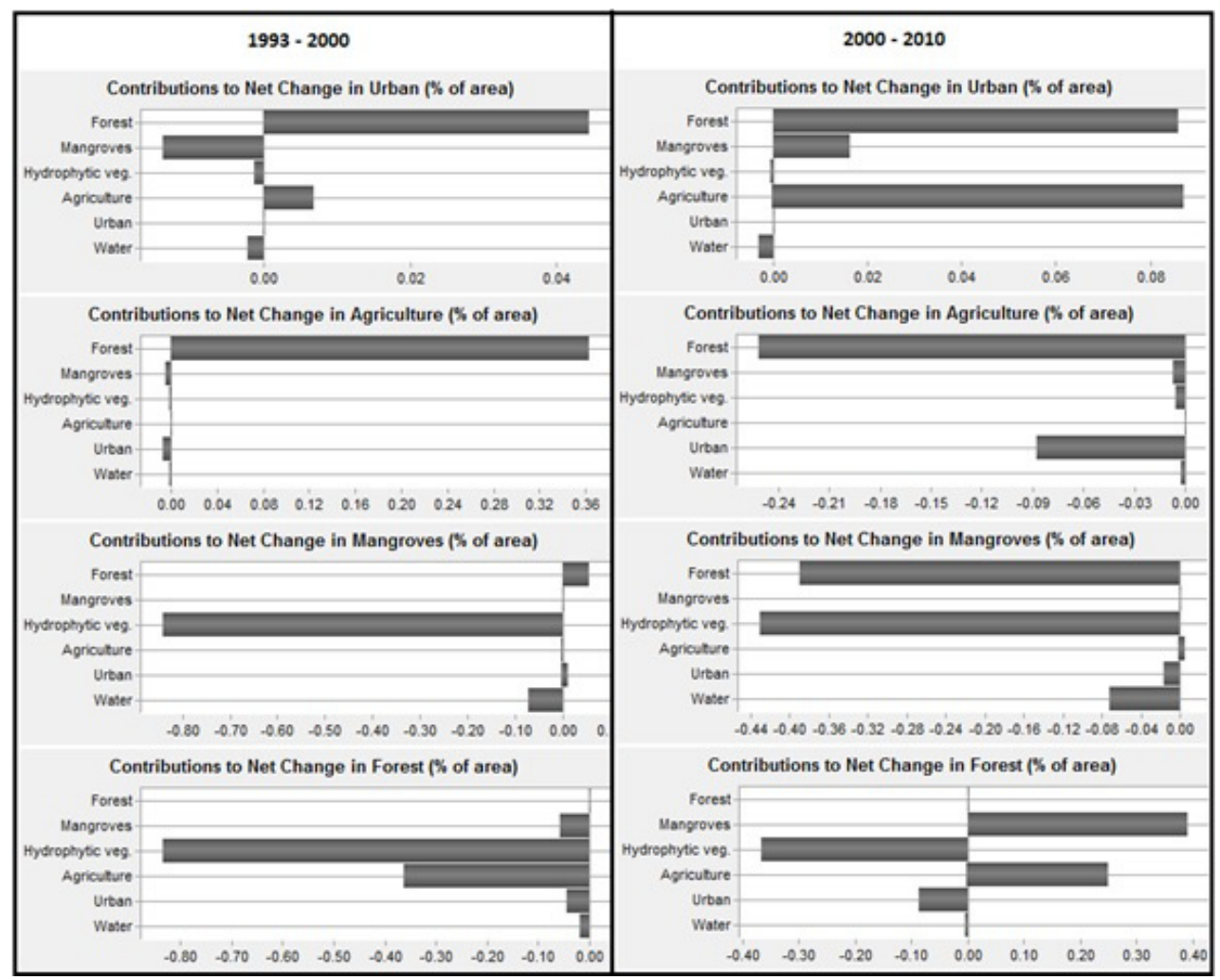

Source: own elaboration.

Fig. 5. Contributions to NET CHANGeS in SELECTEd CATEgories (\% OF STUdy AREA).

Fig. 5. Las Contribuciones al Cambio neto en Cada Cobertura SELecCionada (\% del ÁREA de ESTUDIO). 
Forest loss explains the majority of the total increases in Agricultural areas in the first sub period, while the most significant changes in the second sub period were gains mainly in Forest, Urban and Mangroves, which contributed to a net loss in Agriculture areas.

The major contributors to net loss in Mangroves from 1993-2000 were their conversions to Hydrophytic vegetation and Water, which cancelled out small gains from Forests, whereas, gains in the four classes: Forests, Hydrophytic vegetation, Water, and Urban areas, accounted for the net loss in Mangroves in the period 2000-2010. On the other hand, gains in all other classes contributed to an overall net loss $(1.86 \%$ of the Región Costa Maya) in Tropical forest from 1993-2000. However, the pattern turned around to net gain from 2000-2010, thanks primarily to losses in Mangroves and Agriculture.

\section{Spatial trend of land-cover transitions}

The Región Costa Maya is a socially constructed environment and therefore highly influenced by human activities. To understand broader patterns of change and identify land cover change "hot spots", we used Trend Surface Analysis tab within the Land Change Modeler to map the transition trends from natural vegetation (Tropical forest, Mangrove and Hydrophytic vegetation) to human (Urban area and Agriculture) land covers over the 17-year study period. The resulting map (Fig.6), which was created using a default $3^{\text {rd }}$ order polynomial, depicts a simulated surface that specifies the generalized locations of transitions between selected categories, from areas with no change denoted by Low, to areas with marked change, represented by High.

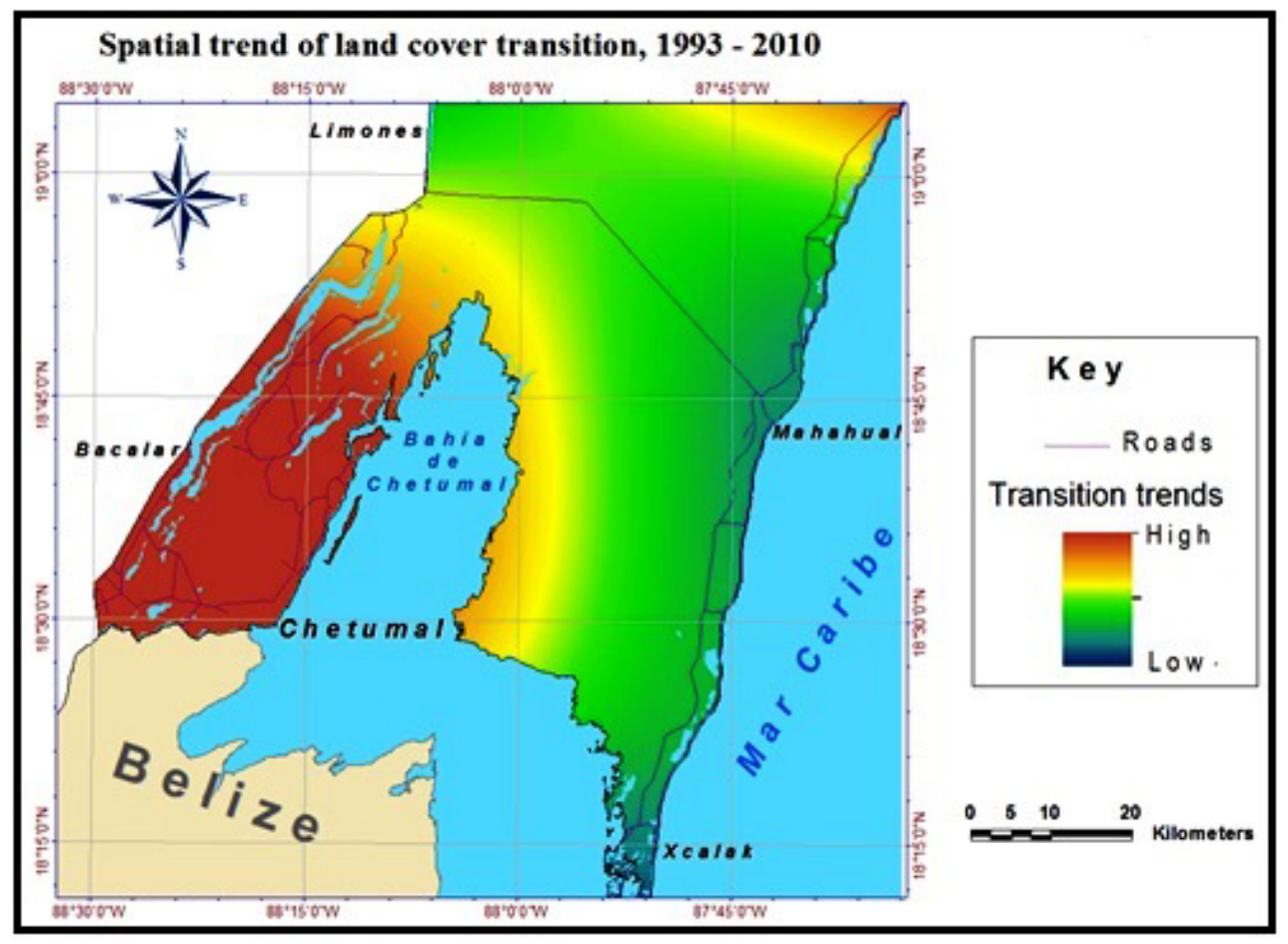

Source: own elaboration.

Fig. 6. Spatial Trend of Land-COVER transitions from natural Vegetation to human land COVERS.

Fig. 6. Tendencia espacial de la transición de COBERTURa natural a COBERTURas artificiales. 
The map reveals a southwesterly tendency of change on the mainland where the most intense propensity for change from natural vegetation to human land covers is concentrated around the south-western portion of Costa Maya, between Bacalar Lake and Bahia de Chetumal (Chetumal Bay) to the Mexico-Belize border. Nochange or persistence, depicted in green, characterized the peninsula and the rest of Costa Maya.

\section{DISCUSSION}

\section{Accuracy assessment}

Research results confirmed the value of segmentation and object oriented classification for mapping and characterizing land cover change, integrating Landsat images and ancillary data. The approach achieved high classification accuracy (94.29\%), well above the recommended target $(>85 \%)$, for satellite-derived land cover maps (FOODY 2002) and a $\boldsymbol{\kappa}$ value (0.9141) which indicates excellent or almost perfect agreement between the map and reference data (MONSERUD \& LEEMANS 1992). These statistics highlight the success of our remote sensing procedures in accurately mapping the spatial distribution of land covers in the Región Costa Maya. Furthermore, the derived high thematic accuracy $(>90 \%)$ resembles those achieved in analogous studies (FROHN, et al., 2009; CECCARELI et al., 2013). Based on these considerations, the derived maps were judged as fit for use in change detection analysis.

Notwithstanding the abovementioned results, some land-cover classes, namely Urban/Agricultural areas with Forest and Mangroves with Hydrophytic plants, presented some mapping problems (Table 2). Urban and Agricultural areas had the lowest omission errors $(>0.2)$ and zero commission errors. This suggests that these errors were probably exaggerated due to the limited representativeness of test samples in these classes, as has been reported in similar studies (CECCARELI et al., 2013). Secondly, mixed categories, like urban, agricultural areas and forest are generally more challenging to classify because their class borders are drawn artificially and a conflict between desired thematic classes and their separation possibilities may exist (FOODY 2002). No wonder these classes suffered from greater commission errors. Thirdly, the 2000 Landsat image was taken in February, during the dry, non-growing season, so some agricultural fields appeared mostly as scrubland and were probably misclassified as Forest. Whereas mangroves and hydrophytic plants exist in similar wet environments, and are often found adjacent to each other, their spectral similarity makes them appear somewhat similar in color on the images, leading to confusion between them (Table 2). All these confusions could have been reduced and the overall accuracy further improved had we carried out further extensive field work, which unfortunately was not logistically possible.

\section{Characteristics of land cover trends}

Change detection results show that urbanization and four other opposite processes, such as deforestation and reforestation; agricultural expansion and land abandonment were active in the Región Costa Maya. Underpinning deforestation from 1993 to 2000 was the expansion of agricultural frontier (Figs .3 \& 5), but when this expansion eventually ended in the second period, forest recovery (at the expense of agricultural areas and mangroves) ensued, reflecting a classic pattern of forest transition, which has been reported to be very common in Latin America (WILLAARTS et al., 2014) and in southern Yucatan peninsula in particular (TURNER II 2010). Places experience forest transitions when declines in forest cover cease and recovery begins through forest regrowth mediated by changing social, economic and political factors (RUDEL et 
al., 2005). Forest transition in the Región Costa Maya can be ascribed to the fact that between 1993 and 2000 agriculture was the principal economic activity along with fishing, and government agricultural policies in the form of subsidies, price controls and prompt distribution of land encouraged deforestation (GEOGHEGAN et al., 2001; TURNER II 2010). However, these policies were later discontinued with the introduction of trade liberalization and a new emphasis placed on tourism (SCHMOOK \& VANCE 2009; VANCE \& GEOGHEGAN 2002). Lack of public investment in rural agriculture in favor of tourism often motivated by conservation rules favored forest recovery, leading to ecosystem recovery (TURNER II 2010; BRAY \& KLEIPEIS 2005).

Even though land abandonment alleviates demands placed on land resources and is positive for environmental recovery, some authors (SERRA, et al., 2008; IGNACIODÍAZ et al., 2011) have warned that it might also have pernicious consequences, such as a gradual decrease in landscape diversity and complexity including an increase of vulnerability to certain hazards such as forest fires, floods, and droughts. We speculated that the reported increased incidents of forest fires in the region might be linked to land abandonment. Besides, land abandonment could also have serious impacts on food security and poor rural lively hood in the Región Costa Maya; given that urbanization is rapidly encroaching and consuming surrounding agricultural areas. Also worrisome is the continued destruction of Mangroves (Fig. 4) at nearly double $(2.2 \%)$ that of the Mexican national average, at an annual mangrove deforestation rate of about $1.3 \%$ (FAO, 2007), reflecting increased human activities (construction of hotels, piers, access roads and through cutting of lines along property boundaries by owners) and hurricanes (DÍAZ-GALLEGOS \& ACOSTA-VELÁZQUEZ 2009; HIRALES-COTA et al., 2010).
Trend surface analysis has revealed the Costa Maya mainland proper, in the Bacalar Lake - Hondo River basin, as a land cover change "hotspot", and not the peninsula as we had expected (Fig. 6). This was undoubtedly attracted by availability of abundant fresh water, proximity to urban areas and road networks. This result should help the authorities to refocus their attention on this particular area in order to correctly manage these rapid changes.

Additionally, some of our change analysis findings are comparable to the results of other published studies that indirectly considered the Costa Maya but used different data sets and remote sensing techniques. For instance, our annual tropical deforestation rate of $0.68 \%$ for the period $1993-2000$, is consistent with $0.76 \%$ estimated by DÍAZGALLEGOS et al. (2010) for southern Quintana Roo during 1976-2000, and with $0.6 \%$ calculated by GARCÍA-RUBIO et al. (2005) for three localities (Ejidos) near Chetumal for the period, 1990-2000. These studies give a further confirmation of the reliability of the change rates we obtained in this study.

\section{CONCLUSIONS}

The study has established a repeatable and efficient image processing workflow based on segmentation and object-based classification for deriving very good and accurate land cover thematic maps from Landsat imagery. These maps are useful in multiple change detection analyses for successful environmental management and understanding. This study has revealed urbanization, agricultural land abandonment (forest transitions) and clearance of mangrove forests to be the principle reasons for land cover change in the Región Costa Maya, fueled mainly by political and socio-economic factors associated with tourism development. From the perspective of conservation planning and management, it appears that the authorities 
have lost total control of the protection of mangrove forests. This is reflected in the continued destruction of mangrove forests, especially in Majahual along the Caribbean coast, despite the fact that mangroves enjoy both national and international protection. Relevant authorities and stakeholders must undertake regular environmental audits on land cover change not only to continuously monitor the conservation status of mangrove forests, but to also ensure that tourism and related infrastructure developments respect existing approved development plans and regulations. One quick and cost effective way of achieving this is by applying the methodology described in this article, taking advantage of the freely available Landsat archive or alternatively, commercial higher resolution imagery.

\section{ACKNOWLEDGEMENTS/ AGRADECIMIENTOS}

This study could not have been achieved without the Scholarship of Excellence by the Mexican Government for foreigners granted to the first author to pursue his doctorate degree at the University of Quintana Roo. Special thanks to Prof. Alessio Zanier Visintin of the University of Quintana Roo for the stylistic revision in English.

\section{REFERENCES}

ASPINALL, R. J. \& HILL, M. J., 2008. Land Use: Science, Policy and Management. New York: CRC Press; Taylor \& Francis Group.

BLASCHKE, T., 2013. Object Based Image Analysis: A New Paradigm In Remote Sensing?, Baltimore, Maryland: ASPRS 2013 Annual Conference.

BLASCHKE, T, HAY G. J., KELLY, M., LANG, S., HOFMANN, P. \& ADDINK, E., 2014. Geographic Object-Based Image Analysis - Towards a new paradigm. ISPRS
Journal of Photogrammetry and Remote Sensing, 87: 180-191.

BLASCHKE, T., JOHANSEN, K. \& TIEDE, D., 2011. Object-Based Image Analysis for Vegetation Mapping and Monitoring. In: Q. Weng, ed. Advances in Environmental Remote Sensing: Sensors, Algorithms, and Applications. Boca Ratón: CRC Press; Taylor \& Francis Group, pp. 241-271.

BRAY, D. B. \& KLEIPEIS, P., 2005. Deforestation, forest transitions, and Institutions for Sustanability in Southeastern México, 1900-2000. Environmetal and History, 11: 195-223.

CECCARELI, T., SMIRAGLIA, D., BAJOCCO, S., RINALDO, S., DE ANGELIS, A., SALVATI, L. \& PERINI, L., 2013. Land cover data from Landsat single-date imagery: an approach integrating pixel-based and object based classifiers. Earopean Journal of Remote Sensing, 46: 699-717.

CAMPBELL, J. B. \& WYNNE, R., 2011. Introduction to Remote Sensing. Quinto ed. New York: The Guilford Press.

CAMPOS-CÁMARA, B. L., 2010. Región turística: Costa Maya. In: B. L. CamposCámara, ed. Análisis territorial del turismo, región Costa Maya. México, D.F: Plaza y Valdés S.A. de C.V, pp. 15-50.

C A S T I L L O - V I L L A N U E VA, L., VELAZQUEZ-TORRES, D. \& LÓPEZMONTEJO, D., 2010. La planeación urbana-regional en Costa Maya. In: B. L. Campos Cámara, ed. Análisis Territorial del Turismo, Región Costa Maya. Madrid, España: Plaza y Valdés Editores, pp. 75110.

CHÁVEZ, P. S. J., 1996. Image-based atmospheric corrections - revisted and improved. Photogrammetric Engineering and Remote Sensing, Issue 1025-1294, p. 62. 
CONGalTON, R. G., 2004. Putting the Map Back in Map Accuracy Assessment. In: R. S. Lunetta \& J. G. Lyon, eds. Remote Sensing and GIS Accuracy Assessment. Boca Ratón, Florida 33431: CRC Press LLC, pp. 1-11.

CONGALTON, R. G. \& GREEN, K., 2009. Assessing the Accuracy of Remotely Sensed Data: Principles and Practices. 2nd ed. Boca Ratón, Florida: CRC Press and Taylor \& Francis Group.

COPPIN, P., JONCKHEERE, NACKAERTS, $\mathrm{K} . \quad \&$ MUYS, B., 2004. Digital change detection methods in ecosystem monitoring: a review. International Journal of Remote Sensing, 25(9): 1565-1596.

DÍAZ-GALLEGOS， J. \& ACOSTAVELÁZQUEZ, I. 2009. In: J. EspinozaAvalos, G. Islebe \& H. Hernández-Arana, eds. El sistema ecológico de la bahía de Chetumal / Corozal, costa occidental del Mar Caribe. Chetumal, Quintana Roo 77014: ECOSUR, pp. 225-237.

DÍAZ-GALLEGOS, J. R., MAS, J.-F. \& VELÁZQUEZ, A., 2010. Trends of tropical deforestation in Southeast México. Singapore Journal of Tropical Geography, 31: 180-196.

EASTMAN, J., 2012. Idrisi Selva Manual. Version 17.01 ed. s.l.: Clark Labs. Clark University, USA.

ESWARAN, H., LAL, R. \& REICH, P., 2001. Land Degradation: An Overview. In: E. Bridges, et al. eds. Response to Land Degradation. Enfield (NH) USA: Science Publishers, pp. 20-34.

FAO, 2007. The world's mangroves 1980 2005. FAO Forestry United Nations Paper 153. Rome, Italy: Food and Agriculture Organization of the United Nations.
FOODY, G., 2003. Remote sensing of tropical forest environments: towards the monitoring of environmental resources for sustainable development. INT. J. Remote Sensing, 24(20): 4035-4046.

FOODY, G. M., 2002. Status of land cover classification accuracy assessment. Remote Sensing of Environment, Volume 80: 185-201.

FROHN, R. C., REIF, M., LANE, C. \& AUTREY, B., 2009. Satellite remote sensing of isolated wetlands using objectoriented classification of Landsat-7 data. WETLANDS, 29(3): 931-941.

GARCÍA-RUBIO, G., SCHMOOK, B. \& ESPEJEL-CARVAJAL, I., 2005. Dinámica en el uso del suelo en tres ejidos cercanos a la ciudad de Chetumal, Quintana Roo. Investigaciones Geográficas, Boletín del Instituto de Geografía, 58: 122-139.

GEIST, H., MCCONNEL, W., LAMBIN, E. F., MORAN, E., ALVES, D. \& RUDEL, T., 2006. Causes and Trajectories of landUse/Cover Change. In: E. F. Lambin \& H. Geist, eds. Land-Use and Land-Cover Change: Local Processes and Global Impacts. Verlag, Berlin, Heidelberg, New York: Springer, pp. 41-70.

EOGHEGAN,J.,CORTINA-VILLAR,S., KLEPEIS, P., MACARIO-MENDOZA, P., OGNEVA-HIMMELBERGER, Y., ROY, R.C., TURNER II, B. L. \& VANCE, C, 2001. Modeling tropical deforestation in the southern Yucatán peninsular region: comparing survey and satellite data. Agriculture, Ecosystems and Environment, 85: 25-46.

GONZÁLEZ-VERA, A., 2010. Mahahual, planeación y sustentabilidad. In: L. CastilloVillanueva, M. E. Orozco-Hernández \& D. Velázquez-Torres, eds. Ciudades, Urbanización y Metropolización. México D.F.: Plaza y Valdés S.A. de C.V., pp. 359374. 
HIRALES-COTA, M., ESPINOZAÁVALOS, J., SCHMOOK, B., RUIZLUNA, A. \& RAMOS-REYES, R., 2010. Agentes de deforestación de manglar en Mahahual-Xcalak, Quintana Roo, sureste de México. Ciencias Marinas, 36(2): 147-159.

HORNING, N., ROBINSON, J. A., STERLING, E. J., TURNER, W. \& SPECTOR, S., 2010. Remote Sensing for Ecology and Conservation: A Handbook of Techniques. First ed. Oxford: Oxford University Press.

IGNACIO-DÍAZ, G., NAHUELHUAL, L., ECHEVERRÍA, C. \& MARÍN, S., 2011. Drivers of land abandonment in Southern Chile and implications for landscape planning. Landscape and Urban Planning, 99: 207-217.

JENSEN, J. R., 1996. Introductory Digital Image Processing: a Remote Sensing Perspective. Segunda ed. New Jersey: Prentice Hall.

LAMBIN, E. F., 1997. Modeling and monitoring land-cover change processes in tropical regions. Progressin Physical Geography, 21(3): 375-393.

LAMBIN, E., GEIST, H. \& LEPERS, E., 2003. Dynamics of Land-use and Landcover change in the Tropical Regions. Annu. Rev. Environ. Resour, 28: 205-241.

LILLESAND, T. M., KIEFER, R. W. \& CHIPMAN, J. W., 2004. Remote sensing and image interpretation. 5th ed. New York: John Wiley \& Sons, Inc.

LIU, D. \& XIA, F., 2010. Assessing object-based clasification: advantages and limitations. Remote Sensing letters, 1(4): 187-194.

LU, D., MAUSEL, P., BRONDÍZIO \& MORAN, E., 2004. Change detection techniques. International Journal of Remote Sensing, 25(12): 2365-2407.
MAS, J., 1999. Monitoring land-cover changes: a comparison of change detection techniques. International Journal of Remote Sensing, 20(1): 139-152.

MONSERUD, R. A. \& LEEMANS, R., 1992. Comparing global vegetation maps with the Kappa statistic. Ecological Modelling, 62(4): 275-293.

NARUMALANI, S., HLADY, J. T. \& JENSEN, J. R., 2005. Information extraction from remotely sensed data. In: J. D. Bossler, J. R. Jensen, R. B. McMaster \& C. Rizos, eds. Manual of Geospatial Science and Technology. New York: Taylor \& Francis, pp. 299-324.

NAVULU, K., 2007. Multispectral Image Analysis Using the Object-Oriented Paradigm. Boca Ratón: CRC Press.

PETIT, C., SCUDDER, T. \& LAMBIN, E., 2000. Quantifying processes of land-cover change by remote sensing: resettlement and rapid land-cover changes in the southerneaster Zambia. International Journal of Remote Sensing, 22(17): 3435-3456.

PRENZEL, B., 2004. Remote sensingbased quantification of land-cover and land-use change for planning. Progress in planning, 61: 281-299.

PUYRAVAUD, J.-P., 2003. Standardizing the calculation of the annual rare of deforestation. Forest Ecology and Management, 177: 593-596.

RUDEL, T. K., COOME, O. T., MORAN, E., ACHARD, F., ANGELSEN, A., XU, J. \& LAMBIN, E.F., 2005. Forest transitions: towards a global understanding of land use change. Global Environmental Change, 15: 23-31.

SCHMOOK, B. \& VANCE, C., 2009. Agricultural Policy, Market Barriers, and Deforestation: The Case of Mexico's Southern Yucatán. World Development, 37(5): 1015-1025. 
SERRA, P., PONS, X. \& SAURI, D., 2008. Land-cover and land-use change in a Mediterranean landscape: A spatial analysis of driving forces integrating biophysical and human factors. Applied Geography, volume 28 , pp. 189-209.

SINGH, A., 1989. Digital change detection techniques using remotely-sensed data. International Journal of Remote Sensing, 21: 2753-2767.

TOMASO, C. et al., 2013. Land cover data from Landsat single-date imagery: an approach integrating pixel-based and object based classifiers. European Journal of Remote Sensing, 46: 699-717.

TURNER II, B., 2010. Sustainability and forest transitions in southern Yucatán: The land architecture approach. Land Use Policy, 27: 170-179.

URIARTE, M., LAURA, S. \& THOMAS, R., 2010. Syenthesis: Land Transittions in the Tropics. BIOTROPICAL, 42(1): 59-62.

VANCE, C. \& GEOGHEGAN, J., 2002. Temporal and spatial modelling of tropical deforestation: a survival analysis linking satellite and household survey data. Agricultural Economics, 27: 317-332.
VÁZQUEZ-TREJO, A., 2010. La Costa Maya, un espacio para la participación de México en la cooperación ambiental centroamericana. In: B. L. Campos-Cámara, ed. Análisis Territorial del Turismo, Región Costa Maya. México D.F.: Plaza y Valdés S.A. de C.V., pp. 153-174.

WANG, Y., MITCHELL, B. R., NUGRANAD-MARZILLI, J., BONYNGE, G., ZHOU, Y. \& SHRIVER, G., 2009. Remote sensing of land-cover change and landscape context of the National Parks: A case study of the Northeast Temperate Network. Remote Sesning of the Environment, 113: 1453-1461.

WILLAARTS, B., SALMORAL, G., FARINACI, J. \& SANZ-SÁNCHEZ, M., 2014. Trends in land use and ecosystem services in Latin America. In: B. Willaarts, A. Garrido \& M. Llamas, eds. Water for Food and Wellbeing in Latin America and the Caribbean. Social and Environmental Implications for a Globalized Economy. Routledge, Oxon and New York: pp. 55-80. 